\title{
Gender Preference in Primary School Enrolment among Households in Northern Region, Ghana
}

\author{
Tia Abdul-Kabiru Mahama \\ Northern Sector Action on Awareness Centre, Tamale, Ghana \\ and \\ Paul Kwame Nkegbe \\ University for Development Studies, Wa Campus, Ghana \\ nkegbe@uds,edu.gh \\ DOI//http://dx.doi.org/10.4314/gjds.v14i1.4
}

\begin{abstract}
Narrowing and eliminating enrolment gaps between male and female children has become a policy issue of governments in developing countries especially with the introduction of the Millennium Development Goals (MDGs) and the post-2015 Sustainable Development Goals (SDGs). The benefits of equal enrolment and retention in primary schools cannot be underestimated for developing countries in particular. This underscores the need for studies that shed light on enrolment inequalities. Applying binary probit model to cross-sectional data from 384 respondents randomly drawn from rural and urban communities in the West Mamprusi District of the Northern Region of Ghana, it is revealed that income level of the household head, number of male and female children of school-age, primary school enrolment decision-maker and number of female children already enrolled are significant determinants of female enrolment. Male children are also found to be the most preferred gender for primary school enrolment. Governments should therefore consider improving income levels of households, as well as sustaining sensitization and awareness creation through the Gender Ministry and/or National Commission for Civic Education on the importance of female education in addressing enrolment inequalities.
\end{abstract}

Keywords: Gender Preference, Household Determinants, Enrolment, Probit Model, Ghana

\section{Introduction}

Education is an investment good (Al-Samarrai \& Peasgood, 1998; Pekkarinen, 2005) and in undertaking such an investment, choice is inevitable. Decision makers would normally consider the returns to each choice against the alternatives. Families with both girls and boys are faced with the choice dilemma in making enrolment 
decisions especially when confronted with resource constraints which, among others, systematically work to produce differences in school enrolment and retention.

Global statistics on enrolment and schooling have shown that about 44 million girls have never been enrolled in school and about 20 Million of them are living in subSaharan Africa (Asare, 2010). Several studies have also pointed to the existence of gender difference in schooling with many attributable causal factors (Amin \& Chandrasekhar, 2009; NDPC, 2010; Sifuna \& Sawamura, 2010). While some of these studies attribute the cause of gender difference to colonial and policy issues (Prah, 2002), others extensively examine the effects of household socio-economic characteristics on schooling (Akyeampong et al., 2007). More so, some authors opine that the difference or gap in enrolment and schooling is inherent in how the household is constellated (Amin, 2009). Assuming that the much-reported difference in enrolment between girls and boys in school is significant ${ }^{5}$, it is a deviation from the ideal situation of $100 \%$ enrolment for both boys and girls which is the goal of all countries (Sattar, 1984). Whatever the preposition for gender difference in primary school enrolment is, households or decision makers are faced with the problem of choice.

Examination of household determinants is necessarily important because the household is a major decision maker in issues of education (Akaguri, 2011; Al-Samarrai \& Peasgood, 1998). Unlike the many studies on this subject matter, this study puts premium on how the characteristics of households potentially affect enrolment decisions. Studies on household characteristics and their effect on primary school enrolment were conducted by Akyeampong et al. (2007) in Ghana, and Al-Samarrai and Peasgood (1998) in Tanzania. These studies suggest that individual and household factors and choice processes influence whether a child, girl or boy, is enrolled in school. Ngware et al. (2008) also in a study in Kenya concluded that household characteristics are important determinants of enrolment. In some of these studies, the assumed important household determinants are usually candidates for analysis, and rightly so, but this phenomenon limits the studies to factors which might not be applicable in other contexts. Also, the assessment of the determinants narrowly explains the effects of household location, gender of the household head, household sibling composition and how the proportions of male to female children and vice versa determine which sex is enrolled in primary school in the Northern region of Ghana. Moreover, there is no adequate statistical determination of the factors influencing primary school enrolment especially on the demand side. This underscores the importance of this paper because it partly examines these issues within the framework of choice analysis. This study takes lessons from the previous studies but diverges from them in approach by using non-linear discrete choice probit model to

5 This assumption is made because this paper does not intend to measure the significance of the difference. 
assess household determinants of primary school enrolment choice in rural and urban communities.

This study empirically analyses primary school enrolment in the Northern region of Ghana, broadening the understanding of enrolment issues and providing the basis for policy makers and change agents to intervene. In providing this understanding, the study draws on the factors affecting enrolment choice between male and female children and the implication for girl child education using the West Mamprusi District of the Northern region as the setting.

The rest of the paper is organised as follows. The next section reviews relevant literature on determinants of school enrolment preference, followed by a section discussing the methodology of the study. The penultimate section contains the presentation of empirical results and discussion of findings from the study, and the final section contains the conclusion and recommendations emanating from the findings of the study.

\section{Determinants of School Enrolment Preference}

Education is one of the ways of securing a good future for children and it is considered a worthy investment to be made by households. Households, however, continually live in scarcity amid unlimited wants. There is therefore the need for choice to be made by the household, but in so doing alternative investment opportunities would be forgone to realise the demand for education. The choice to be enrolled in school is usually determined by the household although the student or pupil may in some circumstances have the decision-making power (Akaguri, 2011; Al-Samarrai \& Peasgood, 1998).

There are different theories (examples are the sibling sex composition theory, the reference group theory, and the reverse group hypothesis) that have been used to explain why the household head would prefer a particular gender to the other for enrolment in school. Economic theories such as the marginal returns theory have also been used by some writers to espouse enrolment choices made. According to Amin (2009), parents tend to invest more in the child with the highest returns on education. This suggests that parents would have to consider boys or girls and take a decision on assumption of which sex has the highest returns to investment (in education). Parents would enrol boys if they are perceived or assumed to have a higher rate of return to education and would enrol girls if they are assumed to have the highest return (Amin, 2009). Choice in this case is solely based on the expected returns to investment to the decision maker.

Budgetary constraints and disutility from any anticipated future inequalities have also been used to explain the choice households make in the context of the sibling sex 
composition by Amin (2009). The composition in simple terms is the boy and girl that the decision maker is to choose from. Resource constraints force decision makers to choose between boys and girls to enrol in school, especially among poor households. Even when the household has the leverage, the fear of future earning inequalities between children could cause the household to favour children who are disadvantaged in the estimation of the decision maker. That is, parents will invest more in the less abled child to make for any earnings inequality and this depends on the ratio of boys to girls in the household (Amin, 2009).

Some of the theories of choice have sociological underpinnings apart from those that are grounded on economics. These explanations also use the sibling sex composition to underscore why a particular sex would be preferred to another. Some parents have greater affection for and attachment to minority sex in the sibling constellation and tend to have preference for them over the majority sex in school enrolment. This is known as the 'sex minority hypothesis' (Amin, 2009). This attachment however varies considerably and it would be simplistic to say that parents or decision makers would enrol either a male or a female in school for the only reason that he or she belongs to the minority sex in the sibling constellation.

The 'relative-change theory' derived from the prospect theory (Omwami, 2012) is also used to explain choice and could provide explanation for choice in school enrolment. According to Omwami (2012), individual choices are made after the assessment of wide range of risky and un-risky options. Decisions are then made through a process where the individual puts values to gains and losses of a particular choice.

In the light of the different choice theories regarding enrolment decision, one can agree with Al-Samarrai and Peasgood (1998) that household schooling decisions is a product of social, cultural and economic factors working through power relations. What variables then determine the choices households make to enrol a girl or a boy in school amidst these economic, social and cultural considerations?

The preference for a particular gender in school enrolment is almost becoming a default part of every human being faced with the problem of choice. In other words, ask anyone his or her choice between a girl and a boy for school enrolment, the person would give a response as if he/she has not reflected on the pros and cons of such a preference. However, preference of a particular gender is usually determined by some factors which probably have been examined over time and internalised by the decision maker.

The literature is replete with many economic reasons, advanced by several writers (see, for instance, de Lange, 2007; ISODEC \& UNICEF, 2011), that explain the enrolment decisions households make and the preference for a particular gender. Antze (2011) argues that the economic reasons for preference are obvious and measurable, and 
possibly explain why it is not too difficult in explaining enrolment and choice. Pal (2004), for instance, finds that gender disparity narrows at higher levels of income especially so when the household is faced with limited resources. This implies that households prefer a particular sex for enrolment to the other because of poverty. Broadly, poverty has been found to have correlation with educational outcomes (Filmer, 1999; GES, 2004a; GSS, 2005; Härmä, 2010; Yidana, 2000) and it is not surprising that poverty would have influence on enrolment preference, especially so when education (and specifically enrolment) has economic underpinnings. The under-representation of girls in primary school system in many developing countries is considered the remnant of poverty because poor households choose to enrol boys (Chamie, 1983).

The choice of boys over girls for school enrolment is not just a factor of poverty because other equally important economic variables influence this choice. Thus, poor households would not choose boys over girls just because of poverty but because of the measurement and priority placed on opportunity cost as observed by Al-Samarrai and Peasgood (1998). Studies (such as Pal, 2004; Rose \& Al-Samarrai, 1997; Taylor \& Mulhall, 1997) have found the opportunity cost of sending a girl to school against the gains of domestic chores, among others, to be higher and hence the preference for boys than girls in school enrolment decision.

Apart from the economic explanation for enrolment preference, there is yet another explanation for the decision households make regarding the sex to be enrolled in school. This explanation is underpinned by culture and values (Akyeampong et al., 2007; Chamie, 1983; ISODEC \& UNICEF, 2011; Taylor \& Mulhall, 1997). In Ghana, for instance, inimical cultural beliefs and practices deny girls of the right of access to education and contribute to the disparity in access to basic education (Asare, 2010). Gender stereotyping has worked against the preference for female as she is viewed as a 'creature for reproduction' rather than for education and related adventures. Early marriage or child marriage is still practised in some communities and the likelihood of preferring a female for enrolment is low. Culture and values may not consistently work against the choice of female for enrolment but could equally affect the choice of male in contrast with the female since communities vary in their cultural beliefs and practices.

A combination and interplay of household characteristics rather than the aforementioned economic and cultural reasons also have influence on preference in school enrolment. Household and individual level characteristics such as the size of household, number of children of school-age and educational background of head of household as well as decision making process influence which child - boy or girl - would be chosen for enrolment in school (Akyeampong et al., 2007; Al-Samarrai \& Peasgood, 1998). Ngware et al. (2008) consider household characteristics as the most important set of factors determining enrolment decision. While there seems to be 
a consensus that education of the household head stimulates education of children in general (see, for example, Rose \& Al-Samarrai, 1997; Shapiro, 2003), there equally seems to be convergence in opinions that household head's education promotes girls' and boys' enrolment in school equally. Households headed by females also prioritise girls' education than households headed by males (Antze, 2011).

Supply side factors are also important determinants of general enrolment and hence gender preference in enrolment. Factors emanating from the educational institutions or schools that can also influence enrolment include school's location, financial cost of schooling, the class size and the content and teaching methodologies of teachers (Antze, 2011; GES, 2004b). The educational environment has been gendered and promotes boys' enrolment and higher attainment than girls' (Prah, 2002; Baden et al., 1994). These stereotyped educational institutions and programmes either discourage female enrolment and education or limit female education to particular sectors. These stereotypes are reflected in the choice parents make in enrolment when they are faced with constraints.

It is therefore obvious from the literature that the preference of parents in enrolment decision is influenced by several factors. Apart from the economic factors, many of the others are not rigid and specific in their influence. In other words, there has been limited measurement of the influence of these factors on preference. Mostly, the household characteristics which stimulate enrolment have been viewed in qualitative terms and little efforts have been made to measure their effects. This paper attempts to provide a kind of measurement to some of the household characteristics and the extent to which they influence enrolment preference.

\section{Methodology}

\section{Study Area}

The study was conducted in four communities in the West Mamprusi District of the Northern region of Ghana. The Northern region is the largest of all the ten administrative regions in Ghana in terms of land mass (occupying about 70,383 square kilometres). The region shares boundaries with the Volta and Brong Ahafo regions to the south, Cote d'Ivoire and Burkina Faso to the west and east respectively and Upper East and Upper West to the north. It has a total population of 2,479,461 inhabitants (GSS, 2012). The region has the lowest school attendance of $50.4 \%$ with wider difference observed between sexes (GSS, 2014). It also has one of the lowest gender parity index of 0.99 at the primary school level as against the national gender parity index of 1 (MoE, 2015). 
The West Mamprusi District is one of the 20 districts $^{6}$ in the Northern region and was created in 1988 by the government of Ghana under LI 1448 with its capital at Walewale (WMDA, 2012). The district is located roughly within longitudes $0^{\circ} 35^{\prime} \mathrm{W}$ and $1^{\circ} 45^{\prime} \mathrm{W}$ and latitude $9^{\circ} 55^{\prime} \mathrm{N}$ and $10^{\circ} 35^{\prime} \mathrm{N}$. The total land area is $5,013 \mathrm{~km}^{2}$ and it shares boundaries with eleven districts namely, Savelugu/Nanton, Karaga, Gushegu, East Mamprusi, Talensi/ Nabdam, Wa East among others (WMDA, 2012). The total population stands at 168,011 inhabitants (83,005 are males and 85,006 females) (GSS, 2012). The female population is below the national average of $51.2 \%$ while the male population is above the national average of $48.8 \%$.

The specific study communities include Walewale, Kukua No. 2, Janga and Daboya No. 2 (refer to Figure 1). Using the classification of the Ghana Statistical Service based on population, Walewale and Janga are urban areas while Kukua No. 2 and Daboya No. 2 are rural.

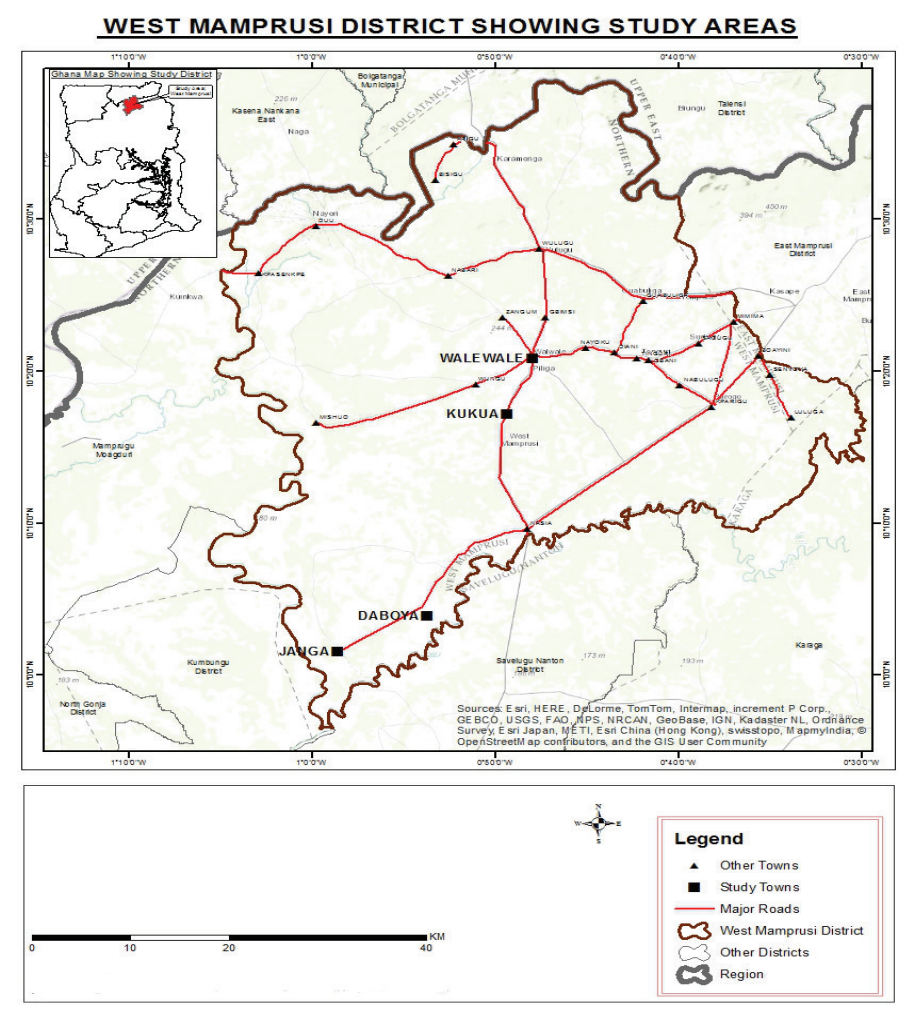

Figure1: Map of West Mamprusi District showing study communities

6 The districts are currently 26 following the creation of new ones. The West Mamprusi District is now divided into two districts (West Mamprusi and Mamprugu/Moaduri Districts). The study was without recourse to the latest division. 


\section{Study Design}

The study employed the stratified sampling procedure to draw a total of 384 respondents from the West Mamprusi District of the Northern region.? This sample was divided into 256 respondents for rural communities and 128 for urban communities based on the proportion of rural to urban households. The primary data were collected between February and April 2013. Majority of the educated in the district have their highest level of education being primary school (GSS, 2005) and a study by Yidana (2000) suggests the existence of gender difference in primary school enrolment. It was therefore interesting to pick such a district for this study. This enabled the situating of predominantly primary school educated population and difference in enrolment within the households. Even though the difference in enrolment was not measured in statistical terms in Yidana's study, it provides a basis for assessing whether or not household characteristics have an influence on choice of males over females. The four communities, namely, Walewale, Janga, Daboya No. 2 and Kukua No. 2, in two educational circuits were selected for the survey through a simple random sampling process. Primary data were then gathered for this study through interviews using semi-structured questionnaires.

\section{Data Analysis}

Primary school enrolment choice between female and male is a categorical (binary) dependent variable. Categorical variables are usually analysed with the aid of qualitative statistical models such as discrete choice models (see, for example, Nkegbe et al., 2012). This is so because the enrolment decision makers would either prefer to enrol male or female children. The binary probit model, which is a nonlinear probability model, is used for the analysis of the data. Even though probit is a qualitative choice model, it affords a quantitative approach to estimating the effects of household characteristics on enrolment preference. Again, the household is faced with a binary choice (enrolling a female or a male) and this shares the property of mutual exclusiveness. The probit and its counterpart, the logit, are better models because the error terms are respectively assumed normally distributed or to possess a logistic distribution and are considered to have similar estimates (Hill et al., 2011).

A rational household is expected to choose the gender that maximises their utility and this is usually based on the linear random utility assumption given as (see, for example, Greene, 2008):

$\left\{\begin{array}{l}U_{i 0}=x_{i 0}+e_{i 0} \\ U_{i 1}=x_{i 1}+e_{i 1}\end{array}\right.$

7 The number of individuals interviewed was arrived at using the formula for sample size determination (see, Godden, 2004). 
where $U_{i 0}$ and $U_{i 1}$ represent the utility of choosing not to enrol and to enrol female children in school respectively, $x_{i}$ represents the household characteristics and $e_{i}$ represents stochastic or error term (i.e. other factors that affect probability of female enrolment other than those specified in $x_{i}$ ). The in the choice model is assumed to be normally distributed hence the use of the probit model.

The probability of choosing either a male or female for enrolment relates to the probability distribution of the error difference in the expected utility of $U_{i 0}$ and $U_{i 1}$ given by:

$$
\begin{aligned}
P_{i} & =\operatorname{Prob}\left(Y_{i}=1 \quad \mid x\right) \\
& =\operatorname{Prob}\left(y_{i}^{*}>0 \quad \mid x\right)=\operatorname{Prob}\left[e_{i}>-x_{i}^{\prime} \beta \mid x\right]=F\left(x^{\prime} \beta\right)
\end{aligned}
$$

where, $\mathrm{F}$ is the cumulative distribution function (cdf) of $e_{i}=\left(e_{i 1}-e_{i 0}\right)$ of evaluated at $x_{i}^{\prime} \beta$ and $y_{i}^{*}=\left(U_{i 1}-U_{i 0}\right)$ is the latent variable and linked to the choice model through the relation:

$y_{i}=\left\{\begin{array}{l}1 \text { if } y_{i}^{*}>0 \\ 0 \text { otherwise }\end{array}\right.$

The probit model thus expresses the probability that (the probability that a female is enrolled) as follows:

$$
\begin{aligned}
P_{i} & =\operatorname{Prob}\left(Y_{i}=1 \mid x\right) \\
& =\Phi\left(\beta_{0}+\beta_{1} X_{1}+\beta_{2} X_{2}+\beta_{3} X_{3}+\ldots+\beta_{n} X_{n}\right)
\end{aligned}
$$

where, $\Phi(\cdot)$ is the standard normal cumulative distribution function (cdf) and the probit function specified as (Hill et al., 2011):

$\Phi(z)=P[Z \leq z]$

$=\int_{-\infty}^{Z} \frac{1}{\pi} e^{-05 u^{2}} d u$

The integral expression is the probability that a standard normal random variable falls to the left of point $z$ or an area under the standard normal probability density function to the left of $z$ in geometric terms (Hill et al., 2011). The general regression model with the categorical response variable and explanatory variables is thus given as:

$y=\beta_{0}+\beta_{1} x_{1}+\beta_{2} x_{2}+\beta_{3} x_{3}+\ldots+\beta_{n} x_{n}+\mu$

where $y$ is the left-hand side (dependent categorical) variable. This is within the framework of multiple regression analysis, but a nonlinear model. The relationship between the expected value of $y$ and the explanatory variables $x_{1}, x_{2}, x_{3}, \ldots, x_{n}$ 
is nonlinear and the distribution of the $\mu$, the error term, is assumed normal. A brief description of these variables is presented in Table 1.

Table 1: Definitions and measurement of variables used in the model

\begin{tabular}{|c|c|}
\hline Variables & Description and Measurement \\
\hline prefgen & $\begin{array}{l}\text { Preferred gender in primary enrolment decision: } 1 \text { if a household head prefers to } \\
\text { enrol female and o otherwise }\end{array}$ \\
\hline age & Age of household head measured in whole years at last birthday \\
\hline income & $\begin{array}{l}\text { Income level of the household head measured as a continuous variable in Ghana cedi } \\
(\mathrm{GH} \pitchfork)^{8} \text { per annum }\end{array}$ \\
\hline fsex & Number of female children of school-going age in the household \\
\hline msex & Number of male children of school-going age in the household \\
\hline decionmaker & $\begin{array}{l}\text { Enrolment decision-maker in the household: } 1 \text { if decision on enrolment is by the } \\
\text { father and o otherwise }\end{array}$ \\
\hline relg & Religious practice of household: 1 if Islam, o otherwise \\
\hline gen & Gender of household head: 1 if male, o if female \\
\hline fchldinsch & $\begin{array}{l}\text { Number of female children enrolled in primary school measured in numbers of } \\
\text { children who have attained schooling age }\end{array}$ \\
\hline location & Location of the household: 1 if it is in rural community and o if in urban community \\
\hline
\end{tabular}

\section{Results and Discussion}

\section{Descriptive Statistics}

The descriptive statistics of important household variables used in this study are presented in Table 2. From the table, the minimum and maximum ages recorded for respondents in rural communities were 22 and 85 years respectively with an average of 45. Similarly, urban respondents had the minimum and maximum ages of 22 and 75 years respectively and a mean age of 40 . A paired t-test of differences in mean ages between rural and urban communities shows no difference even at the $10 \%$ level. The mean age of all respondents in the study area is 43 . Majority of respondents (75.9\%) are youthful falling within the age bracket of 18 to 50 . About $80.7 \%$ of the respondents profess Islam, 16.4\% profess Christianity and about $2.6 \%$ are of the African Traditional faith. About 82.0\% of respondents are male heads of households while the rest are female heads. Primary school enrolment decision is mostly made by the father ( $43.5 \%$ of the cases) in the study area. Only a little over $47.0 \%$ of the respondents have some form of formal education.

8 An exchange rate of US\$1.00 to GHS3.95 was quoted as at 31 July 2016, at http://www.xe.com. 
It is also revealed that about 1,234 children in the two rural communities are of schoolage (568 females and 666 males, giving an average of two females and three males children of school-age per household) and of this number, 913 are enrolled in primary school (476 males and the remaining 437 females, giving an average of two children of both sexes being enrolled in primary school).

Table 2: Household/respondents characteristics

\begin{tabular}{|c|c|c|c|c|}
\hline \multirow[t]{2}{*}{ Characteristic } & \multirow{2}{*}{$\begin{array}{l}\text { Categorisation } \\
\text { Rural }\end{array}$} & \multicolumn{2}{|l|}{ Location } & \multirow{2}{*}{ Total } \\
\hline & & Urban & & \\
\hline \multirow[t]{7}{*}{ Decision maker } & Mother & 38 & 30 & 68 \\
\hline & Father & 115 & 52 & 167 \\
\hline & Child & 8 & 1 & 9 \\
\hline & Both father and Mother & 88 & 45 & 133 \\
\hline & Grand parent & 5 & o & 5 \\
\hline & Others & 2 & 0 & 2 \\
\hline & Total & 256 & 128 & 384 \\
\hline \multirow[t]{3}{*}{ Gender } & Female & 37 & 32 & 69 \\
\hline & Male & 219 & 96 & 315 \\
\hline & Total & 256 & 128 & 384 \\
\hline \multirow[t]{5}{*}{ Religion } & Christianity & 46 & 17 & 63 \\
\hline & Islam & 201 & 109 & 310 \\
\hline & Traditional African & 8 & 2 & 10 \\
\hline & No religion & 1 & o & 1 \\
\hline & Total & 256 & 128 & 384 \\
\hline \multirow[t]{8}{*}{ Age Group } & $20-30$ & 28 & 28 & 56 \\
\hline & $31-40$ & 82 & 53 & 135 \\
\hline & $41-50$ & 81 & 21 & 102 \\
\hline & $51-60$ & 45 & 21 & 66 \\
\hline & $61-70$ & 12 & 3 & 15 \\
\hline & $71-80$ & 6 & 2 & 8 \\
\hline & $81-90$ & 2 & O & 2 \\
\hline & Total & 256 & 128 & 384 \\
\hline \multicolumn{5}{|c|}{ Paired t-test of differences in means } \\
\hline Group & Observation & Mean age & \multicolumn{2}{|c|}{ Standard deviation } \\
\hline Rural & 256 & $44 \cdot 57031$ & \multicolumn{2}{|c|}{11.69091} \\
\hline Urban & 128 & 40.13281 & \multicolumn{2}{|l|}{11.69654} \\
\hline Combined & 384 & 43.09115 & \multicolumn{2}{|l|}{11.86387} \\
\hline \multicolumn{5}{|l|}{ Diagnostics: } \\
\hline$f=09990$ & \multicolumn{2}{|l|}{$H_{0}:$ ratio $=1 \quad H_{a}:$ rc } & \multirow[t]{2}{*}{$v_{1}, v_{2}=$} & 255,127 \\
\hline & $2{ }^{*} \operatorname{Pr}(F<f)$ & $=09813$ & & \\
\hline
\end{tabular}

Source: Authors' analysis 
The urban communities recorded a total number of 434 children of school-age and of this; male children of school-age are 261 whereas female children are 173 with an average of two males to one female. About 328 children of the total children are actually enrolled in primary school (195 males and 133 females) with an average of two male and one female enrollees per household. The rural communities therefore recorded more children of school-age than urban communities for both females and males.

The number of female children of school-age for urban communities is less than males, a case similar to that of rural communities. In the rural communities, the minimum gross income per annum is GH $\$ 180.00$ while the maximum gross income per annum is GH\$9,600.00. The average gross income per household head is GH $\$ 2,478.88$. In the urban communities, the minimum gross income level is $\mathrm{GH} \$ 200.00$ and the maximum income is $\mathrm{GH} \$ 10,260.00$. The average gross income level of all household heads, both rural and urban, is $\mathrm{GH} \pitchfork 2,534.60$.

\section{Preferred Primary School Enrolment Choice}

The most preferred gender by household for primary school enrolment is the male in both rural and urban communities. In rural households, about $67.0 \%$ of the total sample (of 256 respondents) prefers to enrol the male child in contrast with only 33.0\% of respondents preferring to enrol female over male. Among urban households, 71.1\% of the 128 respondents prefer to enrol males while only about $28.9 \%$ prefer to enrol females. Based on household headship, there are 37 female-headed households among the rural households and 21 out of this number, representing 56.8\%, prefer male children enrolment. In contrast, there are 32 female-headed households among the urban households out of which 19, representing 59.4\%, prefer male children enrolment. This reveals that, across gender, the male child is the most preferred for primary school enrolment as against the female child. A test of association between household headship and enrolment preference in the district shows statistical significance only at the $10.0 \%$ level (as shown in the Table 3 ). 
Table 3: Household headship and enrolment preference

\begin{tabular}{|l|l|l|l|}
\hline \multirow{2}{*}{ Household Head } & \multicolumn{2}{|l|}{ Preference } & \multirow{2}{*}{ Total } \\
\cline { 2 - 3 } & Male & Female & \\
\hline Female-headed & 40 & 29 & 69 \\
& $(46.7)$ & $(22.3)$ & $(69.0)$ \\
\hline Male-headed & 220 & 95 & 315 \\
& $(213.3)$ & $(101.7)$ & $(315.0)$ \\
\hline Total & 260 & 124 & 384 \\
& $(260.0)$ & $(124.0)$ & $(384.0)$ \\
\hline $\begin{array}{l}\text { Pearson } \\
\text { Likelihood-ratio }\end{array}$ & & \\
\hline
\end{tabular}

Source: Authors' analysis

\section{Determinants of Female Enrolment}

Table 4 presents the results of the binary probit model. The diagnostic test of the model shows a likelihood ratio (LR) chi-square of 269.46 and the pseudo of 0.5580 and both are significant at the 0.01 level. This also implies that, the explanatory variables, i.e. age of respondents, income of respondents, female composition of children of school-age, male composition of children of school-age in the household, primary school enrolment decision maker in households, religious practice of respondents, gender of respondent, number of female children actually enrolled in school and location of the household head, jointly explain the preference for female primary school enrolment in the West Mamprusi District of the Northern region of Ghana. About $56.0 \%$ of the variation in enrolment is explained by the variables as per the pseudo value of 0.5580 . Overall, the percentage correctly classified by the model is $90.63 \%$ indicating a superior predictive ability of the model. The parameter estimates of the explanatory variables all have the $a$ priori or postulated signs based on the literature - they all show the expected behaviour in respect of choice problem. Age, religion, gender of the household head and location of the household do not significantly explain the choice of female for enrolment in primary school or otherwise. However, income of the household head, number of female and male children of schooling age, primary school enrolment decision maker and number of female children already in school are significant determinants of female primary school enrolment. 
Table 4: Binary probit regression results

\begin{tabular}{|c|c|c|c|c|}
\hline \multicolumn{5}{|c|}{ Dependent variable: Preference for female enrolment } \\
\hline \multirow[t]{2}{*}{ Variables } & \multicolumn{2}{|c|}{ Coefficient estimates } & \multicolumn{2}{|c|}{ Marginal Effects } \\
\hline & Estimates & $\mathrm{SE}^{\mathrm{a}}$ & $\mathrm{dF} / \mathrm{dx}$ & $\mathrm{SE}^{\mathrm{a}}$ \\
\hline age & 0.0083 & 0.0083 & 0.0023 & 0.0023 \\
\hline income & $0.0004^{* * *}$ & 0.0000 & $0.0001^{* * *}$ & 0.0000 \\
\hline fsex & $1.0162^{* * * *}$ & 0.1127 & $0.2843^{* * *}$ & 0.0327 \\
\hline msex & $-0.5529^{* * *}$ & 0.0789 & $-0.1547^{* * *}$ & 0.0219 \\
\hline decionmaker & $-0.4259^{* *}$ & 0.2170 & $-0.1161^{* *}$ & 0.0574 \\
\hline religion & -0.3176 & 0.2383 & -0.0958 & 0.0766 \\
\hline gen & -0.1716 & 0.2848 & -0.0502 & 0.0872 \\
\hline fchldinsch & $-0.5297^{* * *}$ & 0.1152 & $-0.1482^{* * *}$ & 0.0318 \\
\hline location & -0.0716 & 0.2358 & -0.0200 & 0.0658 \\
\hline constant & -1.3105 & 0.6285 & - & - \\
\hline \multicolumn{5}{|c|}{ Model Diagnostics } \\
\hline \multicolumn{5}{|c|}{ Number of observations $=384$} \\
\hline \multicolumn{5}{|c|}{ Likelihood ratio $=269.55 \operatorname{Prob}()=0.0000$ Pseudo $=0.5580$} \\
\hline \multicolumn{5}{|c|}{ Log likelihood $=-106.77775$ Correctly classified $=90.63 \%$} \\
\hline
\end{tabular}

Source: Authors' analysis. Notes: ${ }^{* * *}$, and ${ }^{* *}$ denote statistical significance at the 0.01 and 0.05 levels respectively; ${ }^{\text {a }}$ denotes standard error of the explanatory variables.

Income level of the household head is a significant determinant of preference for female enrolment at the 0.01 level. The marginal effect of income shows that the probability of choosing to enrol female increases by 0.0001 with an increase in income by GH $\$ 1.00$, holding the other factors constant. This is thus consistent with the finding of Kirdar et al. (2007) that significant difference in enrolment is due to household income.

The number of female children of school-age is a significant determinant of the probability of enrolling a female in primary school at the o.01 level and it has a positive correlation with preference for female enrolment. The probability of enrolling female increases by 0.28 with an increase in the number of female children of school-age by 1 , holding other things constant. The reverse is true for the number of male children of school-age. The probability decreases by 0.15 with an increase in the number of male children of school-age. This shows a negative relationship between the probability of female enrolment and the number of male children of school-age. The behaviour of the variables, namely, fsex and msex in the model, is consistent with the assertions by Akyeampong et al. (2007) and Kirdar et al. (2007) that increasing number of children 
of school-age and the number of male children in poorer households will decrease the probability of enrolling female children.

The coefficient of the enrolment decision maker variable shows a negative relationship with choice and it is significant at the 0.05 level. This means, if decision to enrol a child is taken by the father or if decision making power is reversed from say the mother and/ or grandparents to the father, then the probability of a female child being enrolled in school decreases by 0.12. This supports earlier findings by Akyeampong et al. (2007).

The number of female children enrolled in school is a significant determinant of how many more female children will get enrolled in primary school. This variable is significant at the 0.01 level and is negatively related to the probability of enrolling female in school. From the estimates, the probability of female enrolment decreases by about 0.15 as the number of female children already enrolled in school is beyond 2. This is interesting because we have earlier on noted that the number of female children of school-age has positive relationship with the probability of female enrolment in primary school but as the household enrols, a threshold is reached and disutility sets in and this threshold is 2 female children enrolled per household. The 'reference group hypothesis' (Amin, 2009) somehow explains this inverse relationship between female children enrolled in school and the decision to enrol a female.

\section{Conclusion}

The study shows that the male child is the most preferred gender for primary school enrolment irrespective of whether the household head is male or female and irrespective of whether a household is in rural or urban community. Using the binary probit model, it is also revealed that gross income per annum of the household head, the number of female and male children of school-age, the primary school enrolment decision maker and the number of female children already in school are significant determinants of female primary school enrolment.

Within the policy discourse and discussion on measures to increase female school enrolment and retention to achieve gender parity as contained in the universal primary education declaration, this study has provided some insight for policy intervention. It has been established in the study that conscious targeting of male-headed households for sensitization and improving their income levels is one of the practical measures to ensuring girls' enrolment and thereby providing equal opportunities for both girls and boys to be enrolled in school. The study also points to the strengthened role of livelihood and economic empowerment in ensuring female schooling which educational policy makers interested in ensuring gender parity could adopt. Countries, including Ghana, subscribed to the Millennium (and now Sustainable) Development Goals (MDGs/SDGs) 
which contain issues of education and parity in education. Without the underpinning issues as found in this study, pragmatic and responsive measures cannot be designed to address gender inequality in education. This study is therefore very relevant for policy makers and provides practical measures to closing the gap in school enrolment between males and females especially at the basic level within a developing country context.

Important policy issues emanating from the study include livelihood empowerment interventions and income generating activities targeting households and especially the enrolment decision maker other than the father; and sustained sensitization and awareness creation by government through the Ministry of Gender, Children and Social Protection and/or National Commission for Civic Education on the benefits of female education to curtail the observed inverse relationship between female children already enrolled in school and female enrolment.

\section{References}

Akaguri, L.A. (2011). Household choice of schools in rural Ghana: Exploring the contribution and limits of low-fee private schools to education for all. University of Sussex.

Akyeampong, K., Djangmah, J., Seidu, A., Oduro, A. and Hunt, F. (2007). Access to basic education in Ghana: The evidence and the issues, Country Analytic Report (online) Consortium for Research on Education Access, Transition and Equity (CREATE), University of Sussex, Brighton. Available at: https://assets.publishing. service.gov.uk/media/57ao8bfge5274a31eooooef4/Ghana_CAR.pdf. Accessed 2oth May, 2016.

Al-Samarrai, S. and Peasgood, T. (1998). Educational attainments and household characteristics in Tanzania. Economics of Education Review, 17(4), pp. 395-417.

Amin, S. and Chandrasekhar, S. (2009). Looking beyond universal primary education: Gender differences in time use among children in rural Bangladesh (online). Working Paper No. 17. New York, Population Council. Available at: http://www. ungei.org/resources/files/o17.pdf. Accessed 17th November, 2015.

Amin, V. (2009). Sibling sex composition and educational outcomes: A review of theory and evidence for the UK. Labour, 23(1), pp.67-96.

Antze, C.E. (2011). "They should stand on their own feet": Mothers' accounts of education, school choice and their children's uncertain futures in Varanasi, India (online). University of Toronto, Toronto. Available at: https://tspace.library.utoronto.ca/ bitstream/1807/30069/6/Antze_Emily_C_201111_MA_thesis.pdf. Accessed 27th July, 2016. 
Asare, K. (2010). Making Schools Safer for Girls: The Impact of School Infrastructure on Girl's Access to Quality Basic Education in Ghana. Education Watch, Ghana National Education Campaign Coalition (GNEC), Accra.

Baden, S., Green, C., Otoo-Oyortey, N. and Peasgood, T. (1994). Background paper on gender issues in Ghana (online). Report prepared for the West and North Africa Department, Department for Overseas Development (DFID), UK No. 19. Brighton, Institute for Development Studies, BRIDGE (development - gender). Available at: http://www.bridge.ids.ac.uk/sites/bridge.ids.ac.uk/files/reports/re19c.pdf. Accessed 27th July, 2016.

Chamie, M. (1983). National, institutional, and household factors affecting young girls' school attendance in developing societies (online). Washington DC, International Centre for Research on Women and US Agency for International Development. Available at: http://citeseerx.ist.psu.edu/viewdoc/download?doi=10.1.1.455.6349\& rep=rep1\&type=pdf. Accessed 27th July, 2016.

de Lange, A. (2007). Deprived Children and Education in Ghana. Amsterdam: IREWOC.

Filmer, D. (1999). The structure of social disparities in education: Gender and wealth (online). Policy Research Report on Gender and Development, Working Paper Series, No. 5. World Bank. Available at: http://siteresources.worldbank.org/INTG

\section{ENDER/Resources/wp5.pdf. Accessed 27th July, 2016.}

GES (2004a). The Development of Education National Report for Presentation at the FortySeventh Session of the International Conference on Education. Accra: Basic Education Division, Ghana Education Service.

GES (2004b). The Development of Basic Education in Ghana (Presentation at the FortySeventh Session of the International Conference on Education (ICE), Geneva). Accra: Ghana Education Service.

Godden, B. (2004). Sample size and confidence interval. Tutorial 2004. www. williamgodden.com/samplesizeformula.pdf. Accessed 2oth May, 2016

GSS (2005). 2000 Population and Housing Census, Analysis of Districts Data and Implications for Planning: Northern Region. Accra: Ghana Statistical Service.

GSS (2012). 2010 Population \& Housing Census: Summary Report of Final Results. Accra: Ghana Statistical Service.

GSS (2013). 2010 Population \& Housing Census Report: Millennium Development Goals in Ghana. Accra: Ghana Statistical Service.

GSS (2014). Ghana Living Standard Survey 6 (GLSS 6): Main report. Accra: Ghana Statistical Service 
Greene, W.H. (2008). Econometric Analysis (6th ed.). New Jersey: Pearson Education, Inc.

Härmä, J.(2010). School Choice for the Poor? The Limits of Marketisation of Primary Education in Rural India (online). CREATE Pathways to Access Research Monograph No. 23: CREATE. Available at: http://files.eric.ed.gov/fulltext/ED508748.pdf. Accessed 27th July, 2016.

Hill, R.C., Griffiths W.E. and Lim, G.C. (2011). Principles of econometrics (4th ed.). New York: John Wiley and Sons Inc.

ISODEC and UNICEF (2011). The Ghana Shared Growth Agenda, an analysis of the economic policy and budget statement of the Government of Ghana - 2011 gaps and opportunities for women and children. Available at: http://www.isodec.org. gh/publications/Final\%2oDraft\%20UNICEF\%2oBudget\%20Analysis\%202011.pdf. Accessed 17th November, 2015.

Kirdar, G., Murat, D.M. and Tansel, A. (2007). Impact of sibship size, birth order and sex composition on school enrolment in urban Turkey. MPRA Paper No. 2755, Munich Personal RePEc Archive.

MOE (2015). Report on Basic Statistics and Planning Parameters for Basic Education in Ghana 2014/2015. Accra: EMIS, Ministry of Education.

NDPC (2010). Medium-Term National Development Policy Framework: Ghana Shared Growth and Development Agenda, 2010-2013. Accra: National Development Planning Commission.

Ngware, M., Oketch M. and Ezeh, A.C. (2008). Do Household Characteristics Matter in Schooling Decisions in Urban Kenya? APHRC Working Paper No. 37. Nairobi, African Population and Health Research Centre.

Nkegbe, P.K., Kuunibe N. and Abdul-Mumin, Y. (2012). Choice of transport mode by non-resident university students in Ghana. International Journal of Business and Social Science, 3(20), pp.136-142.

Omwami, E.M. (2012). Theoretical and ideological framing: Relative change theory and its application to humanitarianism in education development. US-China Education Review, B3, pp.347-362.

Pal, S. (2004). How much of the gender difference in child school enrolment can be explained? Evidence from rural India. Bulletin of Economic Research, 56(2), pp.133158.

Pekkarinen, T. (2005). Gender differences in educational attainment: Evidence on the role of the Tracking Age from a Finnish quasi-experiment (online). IZA Discussion Paper No. 1897. Bonn: Institute for the Study of Labor (IZA). Available at: http://ftp. iza.org/dp1897.pdf. Accessed 27th July, 2016. 
Prah, M. (2002). Gender issues in Ghanaian tertiary institutions: Women academics and administrators at Cape Coast University. Ghana Studies, 5(1), pp.83-122.

Rose, P. and Al-Samarrai, S. (1997). Household Constraints on Schooling by Gender: Empirical Evidence from Ethiopia. IDS Working Paper 56, Brighton, Institute for Development Studies.

Sattar, E. (1984). Drop-out in primary education: A regional overview. In Towards Universalization of Primary Education in Asia and the Pacific: The Drop-out Problem in Primary Education, Some Case Studies, pp.1-28. Bangkok: UNESCO.

Shapiro, D. (2003). Family Influences on Women's Educational Attainment in Kinshasa. In M. Cosio et al. (Ed.), Education, Family and Population Dynamics (selected papers from a CICRED Seminar held in Ouagadougou, Burkina Faso), pp. 281-304. Committee for International Cooperation in National Research in Demography (CICRED).

Sifuna, D.N. and Sawamura, N. (2010). Challenges of Quality Education in Sub-Saharan Africa-Some Key Issues. New York: Nova Science Publishers Inc.

Taylor, P. and Mulhall, A. (1997). Contextualising teaching and learning in rural primary schools: Using agricultural experience. Education Research Paper No. 20. Department for International Development. Available at: http://rud.dfid.gov.uk/ PDF/Outputs/Misc_Education/paper2oa.pdf. Accessed 17th November, 2015.

WMDA (2012). The Composite Budget of the West Mamprusi District Assembly for the 2012 Fiscal Year. Walewale: West Mamprusi District Assembly.

Yidana, B.M. (2000). Factors Influencing Female Enrolment in Educational Institutions in Ghana: A Case Study of West Mamprusi District of the Northern Region of Ghana. University of Cape Coast, Cape Coast. 